\title{
FÄNGELSETS PLATS I DEN MODERNA KRIMINALPOLITIKEN - STÅR FÄNGELSESTRAFFET INFÖR EN RENÄSSANS?
}

\section{Af Thorsteinn A. JónsSON}

Ud fra et islandsk synspunkt lyder det bagvendt at nævne og behandle spørgsmålet om fængselsstraffens stilling i den moderne kriminalpolitik, ikke mindst spørgsmålet hvorvidt fængselsstraffen står over for en renæssance.

Jeg påstår dette fordi, hvis der i Island tales om moderne kriminalpolitik, så vil der i de andre lande være tale om klassisk kriminalpolitik. Dette kan måske bedre formuleres således, at vi islændinge lige har trådt vores barnesko og er på tærskelen ind i pubertetsalderen angående brug af frihedsstraf.

Fængselsanbringelse som en form for straf for lovovertrædelser blev først indført ved lov i Island i året 1734. Den første fængselsanstalt i Island blev opført i året 1771, efter at byggearbejdet, hvorunder bl. a. domfældte deltog i arbejdet, havde stået på i 10 år. Dette første fængsel i Island var i brug frem til den 5 . november 1813, da det blev lukket. Omkring århundredeskiftet var kårene hos den islandske befolkning meget trange og der herskede hungersnød. Man frygtede simpelthen at nogen ville begå kriminalitet for at komme i fangsel. Forbilledet til det første islandske fængsel var hentet fra de nordiske lande og reglerne som skulle gælde var sammenlignelige med de danske regler. Dog var det klart, at såvel plejen som behandlingen af fangerne var bedre end f. eks. i de danske fængsler og selve bygningen var en langt bedre bolig end de almene boliger i Island. I dag har Islands præsident og statsministeren deres embedskontorer i denne første fængselsanstalt.

Efter at fængslet var blevet lukket i 1813 blev legemsstraf genoptaget undtagen for de mest alvorlige forbrydelser, hvor de strafdømte blev transporteret til afsoning i Danmark. Fra dette tidspunkt fortsatte legemsstraffen som den mest benyttede sanktion frem til året 1875, da et nyt fængsel blev taget $\mathrm{i}$ brug $\mathrm{i}$ Reykjavik og legemsstraf blev endelig afskaffet som en form for straf i 1876 . Den første islandske straffelov er fra året 1869. Heri fandtes imidlertid en provisorisk beføjelse til at bruge legemsstraf, indtil man fik opført fængsler. 
Et af særprægene ved den islandske kriminalpolitik er myndighedernes mangel på interesse. Denne ligegyldighed fremtræder på forskellig vis, for eksempel har statistiske oplysninger ikke været udarbejdet i tilgængelig form om anmeldte kriminelle handlinger, hvordan forbrydelserne opklares eller behandles, hvor mange der indsættes i anstalter og fængsler, det gennemsnitlige daglige belæg, etcetera. Af denne grund har det været vanskeligt at gøre sig klart hvordan udviklingen var tidligere i dette århundrede.

Nogle særpræg fra den islandske straffepraksis og straffuldbyrdelse tidligere i dette århundrede ønsker jeg at gå nærmere ind på.

Den første islandske straffelov er som tidligere nævnt fra året 1869 og var i alle hovedtrækkene bygget på den danske straffelov af 1866. Den islandske straffelov har været underkastet lignende ændringer som den øvrige nordiske straffelovgivning, dog således at ændringerne er indtrådt senere i Island. Den ny og nugældende straffelov er fra året 1940 og som den forrige straffelov bygger den i hovedtrækkene på et dansk forbillede, det vil sige den danske borgerlige straffelov af 1930.

Til trods for ensartede lovbestemmelser har straffuldbyrdelsen udviklet sig anderledes i praksis i Island end i de øvrige nordiske lande.

Allerede $\mathrm{i}$ begyndelsen af århundredet begyndte man at anvende statsoverhovedets benådningsret til at forkorte og formilde de idømte straffe i langt større udstrækning end for eksempel i Danmark. Grunden hertil synes i begyndelsen at have været den, at islændingene havde en anden strafvurdering end straffeloven af 1869 byggede på, og temmelig lang frihedsstraf synes ikke at have været $\mathrm{i}$ overensstemmelse med befolkningens retsbevidsthed. Desuden var fangerne så få, at det ikke viste sig muligt at oprette særskilte anstalter for de forskellige arter af frihedsstraf som straffeloven forudsætter. For det tredje var langvarigt fængselsophold dyrt.

Helt frem til året 1978 var det meget almindeligt, at domfældte kun i ringe grad afsonede deres domme; de blev enten benådet eller simpelthen løsladt inden straffen var udstået og det kaldte man »at afsoningen var udsat « og den resterende straf enten bortfaldt ved indtrædelse af forældelse eller de domfældte fik benådning for reststraffen.

Det er desuden sket tre gange i dette århundrede, at myndighederne har gjort brug af almindelig eftergivelse, benådning, af uafsonede frihedsstraffe.

Et andet kendetegn for straffuldbyrdelsen $i$ dette århundrede helt frem til året 1978 var den udstrakte praksis, at frihedsstraffe ikke blev fuldbyrdet, medmindre der var en særlig grund hertil. Straffen faldt uden videre bort, fordi forældelse indtrådte.

Frem til året 1978 var det politimestrenes opgave at sørge for fuldbyrdelsen af fængselsstraffe. Det var meget forskelligt, hvordan indsættelse og afsoning blev 
gennemført. Det var for exempel ret almindeligt, at personer, som fik en enkelt dom, og ikke begik yderligere kriminalitet herefter, slap for at afsone dommen.

Man er ikke med sikkerhed klar over, hvordan denne slaphed i straffuldbyrdelsen opstod, men det er dog åbenbart, at allerede efter 1930 blev dette tolereret, så den er sandsynligvis begyndt i årene 1920-1930.

Den offentlige kriminalpolitik indebar dog ikke at fuldbyrdelse af domme skulle undlades. Justitsministeriet var godt kendt med situationen uden at det gjorde indvendinger eller foretog sig noget for at ændre på situationen, før end i året 1978.

Det tredje punkt jeg ønsker at fremhæve angående den islandske straffuldbyrdelse, drejer sig om fuldbyrdelsen af hæftedomme for spirituskørsel.

Det var først i året 1926 at det blev strafbart at føre motordrevet køretøj i spirituspåvirket tilstand. Straffen var bødestraf. Dette blev ændret ved en lov, som trådte i kraft den 1. januar 1941, hvorefter spirituskørsel skulle straffes med hæfte eller fængsel. I de første 2-3 år blev denne fuldbyrdelse gennemført i nogen udstrækning. I året 1944 optog myndighederne den skik at ændre straffen efter domfældtes begæring ved benådning til bødestraf og denne fremgangsmåde vedvarede helt frem til 1976. Straffen blev ændret til bøde, uanset om domfældte tidligere var blevet dømt for sådanne forhold, og endog selv om de var blevet idømt strafi henhold til mange domme.

I året 1976 blev fængselsloven ændret og der blev indført en bestemmelse, hvorefter der var hjemmel til at idømme bødestraf. Dette skyldtes først og fremmest den kendsgerning, at der ikke var noget ønske om at genoptage afsoning af hæftedomme og det ansås for mere hensigtsmæssigt, at domstolene idømte den faktiske straf end at myndighederne i realiteten traf den endelige afgørelse.

Situationen er den $\mathrm{i}$ dag angående disse kriminelle forhold, at der normalt idømmes bødestraf i de første 2-3 tilfælde, men hvis der er tale om flere tilfælde idømmes hæftestraf eller fængselsstraf, og de fleste afsoner disse straffe.

Den 1. marts 1978 gennemførtes en radikal ændring hvad angår politikken vedrørende domsfuldbyrdelsen i Island, idet der blev oprettet en særskilt fængselsafdeling i justitsministeriet, som blandt andet sørger for at fuldbyrde alle frihedsstraffedomme. I den forløbne tid fra dette tidspunkt har det hovedprincip været gældende, at alle som er blevet idømt frihedsstraf bør afsone deres domme, og alle som kommer ud fra fængselsanstalterne gør det enten i henhold til gældende regler om prøveløsladelse eller efter endt strafudståelse. Det bør nævnes hvad angår brug af prøveløsladelse, at i henhold til loven gælder den generelle regel, at prøveløsladelse skal ske ved to-tredje-del tid, med mulighed for prøveløsladelse, når halvdelen af straffetiden er udstået når særlige omstæn- 
digheder taler derfor. I praksis løslades flere efter halvtids-reglen end efter to-tredje dels reglen.

Benådning for idømt frihedsstraf er ikke længere et særpræg ved den islandske straffuldbyrdelse. Benådning bruges kun, hvor vægtige grunde taler derfor.

Som tidligere beskrevet foreligger der næsten ingen statistiske oplysninger om kriminalitetsudviklingen, antal domfældte, fangetal, etcetera, undtagen for de sidste 10-20 år.

I året 1970 var det gennemsnitlige daglige belæg 20 fanger per hundrede tusinde indbyggere, og antallet har været stigende siden da. I årene 1980-1984 var tallet steget til 30 fanger pr. 100.000 indbyggere, og fra året 1985 har stigningen været raskt voksende, således at i sidste år, 1988, var det gennemsnitlige daglige belæg 38 indsatte pr. 100.000 indbyggere.

Der findes ikke nogen enkel forklaring på denne udvikling og stærke stigning. Antallet af anmeldte forbrydelser er vokset, men dog ikke i trit med fangetallet. De væsentligste forklaringer som jeg har er følgende: For det første, at strukturændringen i 1978 medførte et større antal indsatte. For det andet førte en ændring af strafferetsplejeloven i 1977 til ansættelse af flere kriminalpolitifolk og en højere standard på efterforskningsarbejdet. For det tredje mener jeg - selv om det ikke er påvist - at recidivister har været mere aktive end tidligere, hvilket betyder forholdsvis flere strafbare handlinger og derved strengere straffe. For det fjerde mener jeg - selv om det heller ikke er påvist - at strafudmålingen hos domstolene har ændret sig i retning mod strengere straf, end der tidligere blev anvendt. Det sidste gælder navnlig om forbrydelser mod kønssædeligheden, grovere vold og legemskrænkelser samt vaneforbrydere. Fra året 1970 er antallet af ubetingede frihedsstraffedomme vokset med ca. $250 \%$, men gennemsnitlig er den faktiske idømte straf $35 \%$ kortere end dengang.

Jeg finder det særdeles interessant at undersøge i hvilke tilfælde samfundet benytter frihedsstraf som et middel til at modvirke lovovertrædelser, og det er ikke mindre interessant at undersøge i hvilke tilfælde denne straf $i k k e$ benyttes. I bemærkningerne til straffeloven af 1940 hed det: »Formålet med straffen er først og fremmest at sikre retssikkerheden og opretholdelsen af den lovbestemte samfundsordning. Desuden udsoner straffen retfærdighedsfølelsen hos befolkningen, der ikke accepterer at væsentlige rettigheder hos andre borgere krænkes uden straf.«

Fanger i Island kan opdeles i fire hovedgrupper ifølge straffegrundlaget:

1. Ca. $15 \%$ af indsatte afsoner dom for vold, d. v. s. manddrab, vold, overfald, røveri, sædelighedsforbrydelser, og så videre.

2. Ca. $50 \%$ afsoner straf for berigelsesforbrydelser og dokumentfalsk. 
3. Ca. $10 \%$ af fangetallet afsoner domme for narkotikalovovertrædelser.

4. Ca. $20 \%$ afsoner promille- og spirituskørsel samt kørsel uden førerrettigheder.

Når denne fordeling undersøges nærmere viser det sig, at det ikke er selve overtrædelsen som er af afgørende betydning hvad angår anvendelse af frihedsstraf; det kan tværtimod begrundes at for de tre førstnævnte grupper, d. v.s. volds-, berigelses- og narkotikaforbrydelser, anvendes frihedsstraffen for at tilfredsstille befolkningens såkaldte retfærdighedsfølelse.

Liv, åndeligt og legemligt helbred er nogle af de allervigtigste goder som den enkelte har, og der opstår meget kraftige reaktioner når disse goder angribes. Kravet om straf og selve straffen er først og fremmest hævn. Når voldsgruppen iagttages nærmere kan den faktisk opdeles i to kategorier, d. v. s. de farlige voldsforbrydere og andre lovovertrædere, hvor årsagen til gerningen skyldes vedkommendes særlige forhold. Mindstedelen af dem, der begår voldsforbrydelser, er farlige.

Som tidligere nævnt afsoner ca. halvdelen af de indsatte domme for berigelsesforbrydelser og dokumentfalsk. Langt den største del af disse fanger er de såkaldte vaneforbrydere, det vil sige de afsoner domme for de traditionelle forbrydelser som for eksempel indbrud, tyveri, checkfalsk, etcetera. De fleste af disse mennesker er bukket under i livskampen eller lever af en eller anden grund ikke i overensstemmelse med det traditionelle samfundsmønster.

I det sidste århundrede og først i dette århundrede var der meget vægtige grunde til at krænkelse af ejendomsretten nød en udstrakt strafferetlig beskyttelse. Fattigdom var herskende og tiderne var meget trange. Derfor måtte familien sørge for at familiemedlemmerne overlevede. Tyveri af f. eks. madvarer og beklædningsgenstande kunne derfor indebære meget alvorlige følger for offeret og dennes familie. Man kan sige at i begyndelsen svarede straffen til overtrædelsens eventuelle følger.

Endnu i dag straffes lige hårdt for denne eller lignende typer af overtrædelser selv om følgerne for offeret er ganske anderledes end tidligere. Et typisk tyveri har næsten aldrig den følge længere, at det kan være spørgsmål, om offeret overlever. Arsagen hertil er, at folk økonomisk er meget bedre stillet, og desuden får de ofte deres tab eller skade erstattet gennem forsikringer.

Til trods for denne omvæltning af forudsætningerne bruges fortsat frihedsstraf forsåvidt angår denne type af overtrædelser for at tilfredsstille eller udsone folkeopinionen. Ikke mindst er grundene hertil, at overtrædelserne er rettet mod vel definerede personlige objekter, lovovertræderne lever ikke efter et traditionelt samfundsmønster og også det, som ikke har mindst betydning, at dette er en type sager, som retssystemet og domstolene behersker godt. Sagsfremstillingen og behandlingen er forholdsvis enkel, hvor den strafbare handling er klart af- 
grænset og den falder godt ind under straffelovens definitioner, og gerningsmændene har på grund af deres stilling ikke nogen mulighed for at benytte sig af retssystemets svage punkter.

Hvis den »gennemsnitlige« samfundsborger begår en overtrædelse, der falder under denne gruppe af forbrydelser, kræves der meget mere til at han idømmes uvilkårlig frihedsstraf end hvis der var tale om en undermåler. Spørgsmålet, som vi står overfor, er derfor dette: Er vi kommet langt væk fra det formål der blev sat $\mathrm{i}$ begyndelsen, nemlig at anvende frihedsstraf for at kæmpe imod plagen af landstrygere og vagabonder?

Den tredje gruppe jeg nævnte som et eksempel på at udsone almenhedens opinion, er den gruppe af personer, som overtræder narkotikalovgivningen. Ganske vist er situationen lidt anderledes end i de to tidligere grupper. Her mangler man offeret, men befolkningen kræver frihedsstraf og den idømmes. Det er kun i forbindelse med forsætligt manddrab og andre grove voldsforbrydelser som der anvendes uvilkårlig frihedsstraf i lige så stor udstrækning som i narkotikasager. Jeg må erkende, at jeg ikke er helt klar over, hvorfor frihedsstraffe faktisk anvendes i den store udstrækning som det er tilfældet i narkotikasager. Det kan nok tænkes, at usikkerheden og angsten for følgerne, såvel for enkeltpersoner som for samfundet i dens helhed her spiller en rolle, d. v. s. fordi forbruget kan føre til opløsning og nedbrydning af det gældende samfundssystem. En anden årsag kan måske være den, at narkotikaovertrædelser er næsten den eneste form for kriminelle handlinger, hvor der her i Norden er tale om organiseret kriminalitet.

Den fjerde hovedgruppe af indsatte afsoner straf for promille- og spirituskørsel samt for kørsel uden førerrettigheder. Dette er den eneste gruppe af lovovertrædelser, hvor almenheden ikke kræver frihedsstraf. Det er åbenlyst, at promille- og spirituskørsel kan medføre alvorlige følger. I Island sigtes omkring 2500 personer per år for promille/spirituskørsel, eller ca. 1,3\% af alle islændinge som er 15 år og ældre. Det er kun en lille brøkdel af disse som faktisk forvolder skade eller pågribes i faretruende situationer i trafikken. Dette er et af de klareste eksempler, som vi har, med henblik på at forsøge at påvirke den almindelige holdning med hårde sanktioner. Her blomstrer strafferettens ideologi om såvel den generalpræventive som den specialpræventive virkning. Jeg stiller et stort spørgsmål ved dette og spørger, om det ikke kan tænkes, at en anden straffeform som vi har til rådighed, kan gøre samme nytte.

Jeg nævnte her foran, at det er interessant at kigge nærmere på de tilfælde, hvor der ikke eller næsten ikke anvendes frihedsstraf. En velfærdsstat, som påtager sig at sørge for væsentlige dele af forsorgen, f. eks. uddannelse, helbred og andre 
sociale ydelser, koster en del at drive, og det kræver opretholdelse af et indviklet system af mangeartede skatter og afgifter at holde dette gående. Det er en erkendelse, at en hel del af de skatter og afgifter, som skal indgå for at bidrage til de fælles samfundsopgaver slet ikke indløber som de skal, og her er der tale om meget store beløb. Det er uhyre sjældent, at nogen kommer i fængsel for »forseelser« af denne type, endog selv om de opklares og der er tale om store beløb. Befolkningens holdning er anderledes til denne type af overtrædelser, der som oftest ikke retter sig mod enkelte personer, men derimod mod samfundet i dets helhed, til trods for at skadevirkningerne er mindst lige så store som i de tilfælde, hvor frihedsstraf idømmes. Bag dette ligger der mangeartede grunde. Lovovertræderen er normalt en »gennemsnitsborger«; den kriminelle virksomhed er systematisk og efterforskning af denne slags sager er både tidskrævende og teknisk vanskelig og herudover er lovgivningens definitioner sådan beskaffen, at »forseelser« af denne type har svært ved at falde under straffelovens bestemmelser.

Her kan der nævnes flere tilfælde, som f. eks. hvor overtrædelserne er rettet mod miljøet og endog således, at livsbetingelserne for et ubestemt antal mennesker bringes i fare. »Forseelser« af denne type fører ikke til frihedsstraf.

Jeg kan ikke få øje på noget, der tyder på andet end at frihedsstraffen har en lys fremtid.

Borgerne vil fortsat kræve frihedsstraf og man vil give efter for dette krav. Det er dyrt at drive fængsler og derfor vil myndighederne til stadighed forsøge at begrænse anvendelse af frihedsstraf i videst mulig udstrækning. Dette kan føre derhen, at sagerne vægtes indbyrdes, og at fængselspladserne prioriteres $\mathrm{i}$ en anden rækkefølge end $\mathrm{i}$ dag. Voldsforbrydere vil være højest prioriterede, og hvis de fylder en væsentlig større del af fængselspladserne end de nu gør, har jeg svært ved at gøre mig det klart, hvilken gruppe der må vige pladsen for dem.

Thorsteinn A. Jónsson, Afdelingschef, justitsministeriet, Reykjavik. 